\title{
Fertility in male mice lacking NO-sensitive guanylyl cyclase
}

\author{
Dieter Groneberg ${ }^{1 *}$, Peter König ${ }^{2}$, Andreas Friebe ${ }^{1}$ \\ From 5th International Conference on CGMP: Generators, Effectors and Therapeutic Implications \\ Halle, Germany. 24-26 June 2011
}

\section{Background}

The NO/cGMP signal transduction is involved in the regulation of a variety of physiological processes e.g. smooth muscle relaxation, inhibition of platelet aggregation and synaptic plasticity. Nitric oxide $(\mathrm{NO})$ is produced by NO synthases and acts mainly on NOsensitive guanylyl cyclase (NO-GC), the most important $\mathrm{NO}$ receptor. NO stimulation of NO-GC leads to production of the second messenger cGMP which exerts its effects via cGMP-dependent kinases, channels or phosphodiesterases.

\section{Methodology}

Recently, we have generated mice lacking NO-GC (GCKO). We showed that lack of NO-GC resulted in arterial hypertension concomitant with a totally abolished NO responsiveness of vascular and gastrointestinal smooth muscle.

Global deletion of a protein in mice does not allow identification of the cell/tissue type responsible for a certain phenotype. We therefore generated a mouse line in which NO-GC was specifically deleted in smooth muscle cells (SM-GCKO). These mice should provide more detailed information on the role of NO and cGMP with regards to smooth muscle relaxation.

\section{Results}

Here we examined the role of NO/cGMP signaling with regards to the smooth muscle relaxation of corpus cavernosum. NO failed to relax corpus cavernosum from GCKO in organ bath experiments: neither exogenously produced NO by NO donors nor endogenous NO release from neurons induced by electrical field stimulation led to relaxation. Similar results were observed in

\footnotetext{
* Correspondence: dieter.groneberg@uni-wuerzburg.de

'Physiologisches Institut, Universität Würzburg, Germany

Full list of author information is available at the end of the article
}

the corpus cavernosum of SM-GCKO mice. To our surprise, both $\mathrm{KO}$ models were fertile and produce offspring.

\section{Conclusion}

Our data show that deletion of NO-GC globally or exclusively in smooth muscle abolishes corpus cavernosum relaxation, but nevertheless, does not impair fertility.

\section{Author details}

${ }^{1}$ Physiologisches Institut, Universität Würzburg, Germany. ${ }^{2}$ Institut für Anatomie, Universität Lübeck, Germany.

Published: 1 August 2011

doi:10.1186/1471-2210-11-S1-P30

Cite this article as: Groneberg et al:: Fertility in male mice lacking NOsensitive guanylyl cyclase. BMC Pharmacology 2011 11(Suppl 1):P30.
Submit your next manuscript to BioMed Central and take full advantage of:

- Convenient online submission

- Thorough peer review

- No space constraints or color figure charges

- Immediate publication on acceptance

- Inclusion in PubMed, CAS, Scopus and Google Scholar

- Research which is freely available for redistribution
C Biomed Central

\section{Biomed Central}

(c) 2011 Groneberg et al; licensee BioMed Central Ltd. This is an open access article distributed under the terms of the Creative Commons Attribution License (http://creativecommons.org/licenses/by/2.0), which permits unrestricted use, distribution, and reproduction in any medium, provided the original work is properly cited. 